\title{
Membranoproliferative glomerulonephritis, mantle cell lymphoma infiltration, and acute kidney injury
}

\author{
Arkadiusz Lubas • Andrzej Mróz • \\ Jerzy Smoszna $\cdot$ Stanisław Niemczyk
}

Received: 6 December 2011/ Accepted: 21 May 2012/Published online: 1 July 2012

(C) The Author(s) 2012. This article is published with open access at Springerlink.com

\begin{abstract}
Mantle cell lymphoma (MCL) is a rare aggressive lymphoid neoplasm occurring in about 3-7\% of non-Hodgkin lymphomas in the United States and Europe. Although lymphomas infiltrations are recognized in about half of post-mortem studies, in available literature we found only eight cases of mantle cell lymphoma with renal involvement. Five of them present MCL related glomerulonephritis, two show renal MCL infiltration with acute kidney injury and the last one describes MCL infiltration with acute tubulo-intrerstitial nephritis. We present the first case of a patient with the coexistence of renal mantle cell lymphoma infiltration, subacute membranoproliferative glomerulonephritis and acute kidney injury.
\end{abstract}

Keywords Mantle cell lymphoma - Kidney infiltration · Glomerulonephritis · Acute kidney injury

A. Lubas $(\varangle) \cdot$ J. Smoszna $\cdot$ S. Niemczyk

Department of Internal Medicine, Nephrology and Dialysotherapy, Military Institute of Medicine, ul. Szaserów 128, 04-141 Warsaw 44, Poland e-mail: alubas@wim.mil.pl

\section{A. Mróz}

Department of Gastroenterology and Hepatology, Medical Center for Postgraduate Education, ul. Roentgena 5, 02-781 Warsaw, Poland

\section{Case report}

Patient B.C., age 59, was admitted to the Clinic of Nephrology in August 2011 with a suspected rapidly progressing glomerulonephritis. In an interview, the patient described the existence of eczema present for about 5 years, on face, chest, back and limbs recognized as rosacea-like dermatitis. So far performed diagnostics has found markers of eosinophilia increasing since $2008(0.55-2.42 \mathrm{~g} / \mathrm{l})$ and neck lymphadenopathy (lymph nodes up to $8 \times 25 \mathrm{~mm}$ ) without further diagnostics. In 2008, the patient was temporarily treated orally with methylprednisolone and cetirizine. Additional diagnostics performed in June 2010, during another stay at the Clinic of Dermatology, discovered high concentration of total $\mathrm{IgE}$ (20.44 g/l), slight impairment of renal function (creatinine $106.08 \mu \mathrm{mol} / \mathrm{l}$, GFR-MDRD $67 \mathrm{ml} / \mathrm{min} /$ $\left.1.73 \mathrm{~m}^{2}\right)$ with proteinuria $(0.5 \mathrm{~g} / \mathrm{l})$ and hematuria (16-25/high-power field) suggesting glomerulonephritis, hypercholesterolemia $(6.7 \mathrm{mmol} / \mathrm{l})$, hyperbilirubinemia $(32.8 \mu \mathrm{mol} / \mathrm{l})$ and elevated erythrocyte sedimentation rate $(28 \mathrm{~mm} / \mathrm{h})$. In May 2011 , hemorrhagic, Henoch-Schönlein-like purpura of hands, feet and legs joined the existing eczema. For this reason, in July 2011 the patient was hospitalized in the Clinic of Infectious Diseases and Allergology, where persistent features of glomerulonephritis with proteinuria $0.45 \mathrm{~g} / 24 \mathrm{~h}$, elevated levels of $\operatorname{sIgA}(8.37 \mathrm{~g} / \mathrm{l})$, and proper kidney function (creatinine $79.56 \mu \mathrm{mol} / \mathrm{l}$, GFR-MDRD $92 \mathrm{ml} / \mathrm{min} / 1.73 \mathrm{~m}^{2}$ ) were confirmed. A 
chest radiograph indicated a widened shadow of the right mediastinum. An ultrasound examination visualized numerous enlarged peripheral lymph nodes in the neck (up to $13 \times 37 \mathrm{~mm}$ ), enlarged spleen, and stones of 5-9 $\mathrm{mm}$ in both kidneys. A biopsy of the skin revealed erythema elevatum with neutrophilic, eosinophilic and lymphocytic infiltration around vessels. As a complication of the biopsy, erysipelas of the left upper limb occurred (August 2011), with a fever up to $39{ }^{\circ} \mathrm{C}$, treated successfully with the second- and thirdgeneration cephalosporins and metronidazole. During the treatment, progressive deterioration of renal function was found. At the admission to the Clinic of Nephrology, the patient did not report any essential ailments. Additional diagnostics revealed signs of progressive multi-organ failure: kidney with nephrotic syndrome (creatinine $772.92 \mu \mathrm{mol} / \mathrm{l}$, GFR-MDRD $7 \mathrm{ml} / \mathrm{min} / 1.73 \mathrm{~m}^{2}$; urea $27.89 \mathrm{mmol} / \mathrm{l}$; albumin $25 \mathrm{~g} / \mathrm{l}$; proteinuria $6.88 \mathrm{~g} / 24 \mathrm{~h}$ with preserved diuresis $2.5 \mathrm{l} / 24 \mathrm{~h}$ ), liver (bilirubin $131.67 \mu \mathrm{mol} / \mathrm{l}$, GGTP 2,938 U/l; AST 119 U/l, ALT185 U/l), and hematopoietic system $(\mathrm{Hgb} 77 \mathrm{~g} / \mathrm{l})$ with the complement system activation $\left(\mathrm{C}_{3} \quad 0.23 \mathrm{~g} / \mathrm{l} ; \mathrm{C}_{4} \quad 0.01 \mathrm{~g} / \mathrm{l}\right)$. The presence of ANA, p- and c-ANCA antibodies was not confirmed, but the level of dsDNA antibodies was elevated up to $44 \mathrm{IU} / \mathrm{ml}$. Ultrasound abdomen examination showed enlargement of the kidneys (left kidney length $141 \mathrm{~mm}$, right kidney $134 \mathrm{~mm}$ ) with signs of the parenchyma swelling and bilateral kidney stones. Therefore, it was decided to initiate temporary renal replacement therapy by hemodialysis every second day, using a central venous catheter. At the same time, between hemodialysis, immunosuppressive therapy with i.v. infusions of $3 \times 1.0 \mathrm{~g}$ methylprednisolone was started. The treatment continued with oral administration of $60 \mathrm{mg}$ prednisone daily. The red blood cell concentrate was transfused. After three hemodialysis interventions, a significant improvement in renal function was achieved, and renal replacement therapy was no longer required (creatinine $114.92 \mu \mathrm{mol} / \mathrm{l}$, GFR-MDRD $60 \mathrm{ml} / \mathrm{min} /$ $1.73 \mathrm{~m}^{2}$, urea $\left.8.3 \mathrm{mmol} / \mathrm{l}\right)$. Moreover, both normalization of liver function (bilirubin $13.68 \mu \mathrm{mol} / \mathrm{l}$, GGTP $772 \mathrm{U} / \mathrm{l}$, AST $16 \mathrm{U} / \mathrm{l}$, ALT $28 \mathrm{U} / \mathrm{l})$ and correction of anemia (Hgb $101 \mathrm{~g} / \mathrm{l})$ were achieved. A biopsy of the left kidney and a cervical lymph node was collected for histopathological evaluation. Based on the preliminary result of the renal biopsy, in which active lesions were found in the form of vascular loops necrosis and cellular crescents, intravenous infusion of $1.0 \mathrm{~g}$ of cyclophosphamide was administered.

Renal core biopsy submitted for embedding contained 10 glomeruli and cortex parenchyma. On histological examination, several foci of dense lymphocytic infiltration were found. These foci concentrated mainly around glomeruli and consisted of medium-sized slightly atypic lymphocytes with sparse cytoplasm. The nuclei were of similar size and cytological features and stayed in close intimacy with each other without overt molding (Fig. 1). Immunohistochemical studies revealed expression of CD20, CD5 and cyclin D1 markers, while CD3 staining was
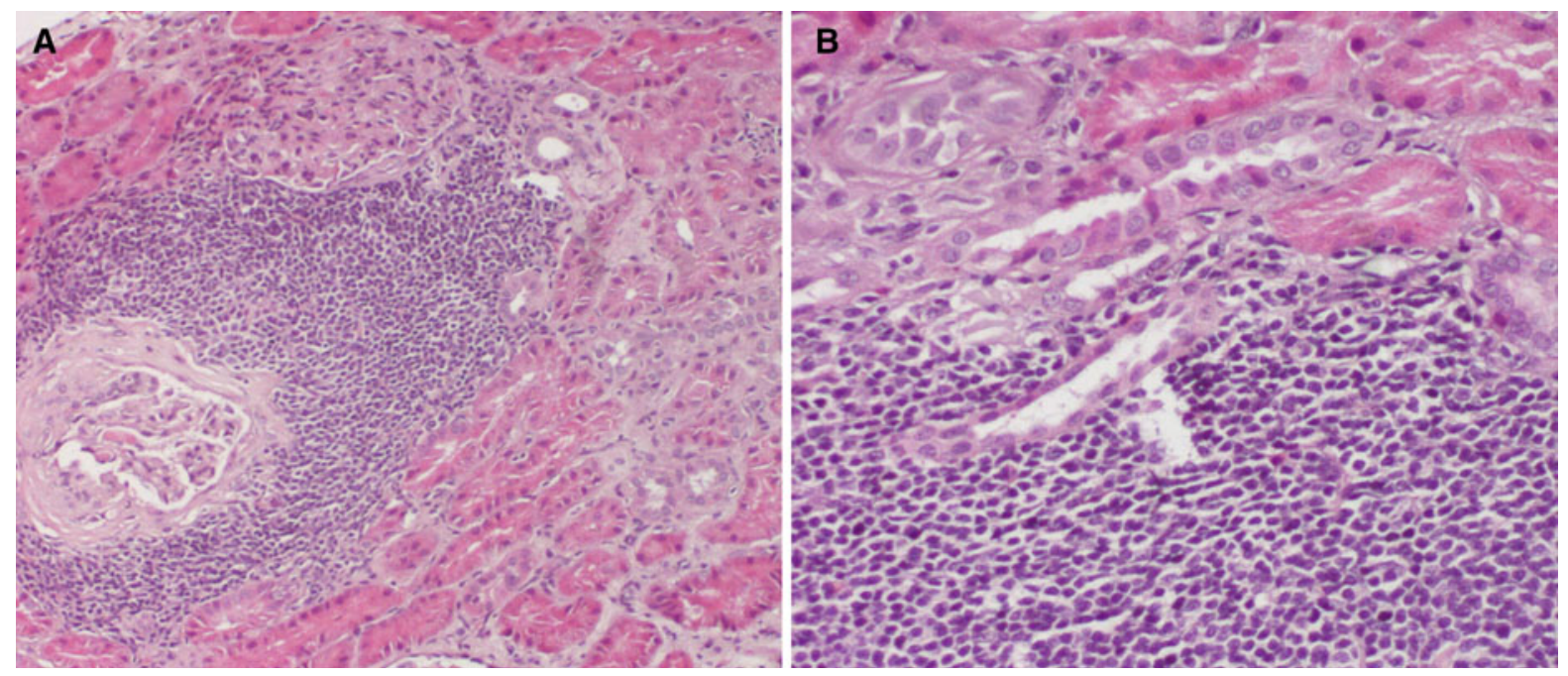

Fig. 1 Mantle cell lymphoma infiltration in renal cortex $(\mathrm{HE}, \mathbf{a} \times 100, \mathbf{b} \times 200)$ 
positive only in non-neoplastic cells (Figs. 2, 3). The Ki-67 staining displayed a low mitotic activity with the expression in about $20 \%$ nuclei (Fig. 4). These morphology and immunoprofile justified the diagnosis of mantle cell lymphoma invading renal parenchyma. In addition, the biopsy showed features of membranoproliferative glomerulonephritis including mesangial proliferation and basal membranes thickening and double contouring (Fig. 5). Segmental, cellular crescents were present in 2 of 10 glomeruli as
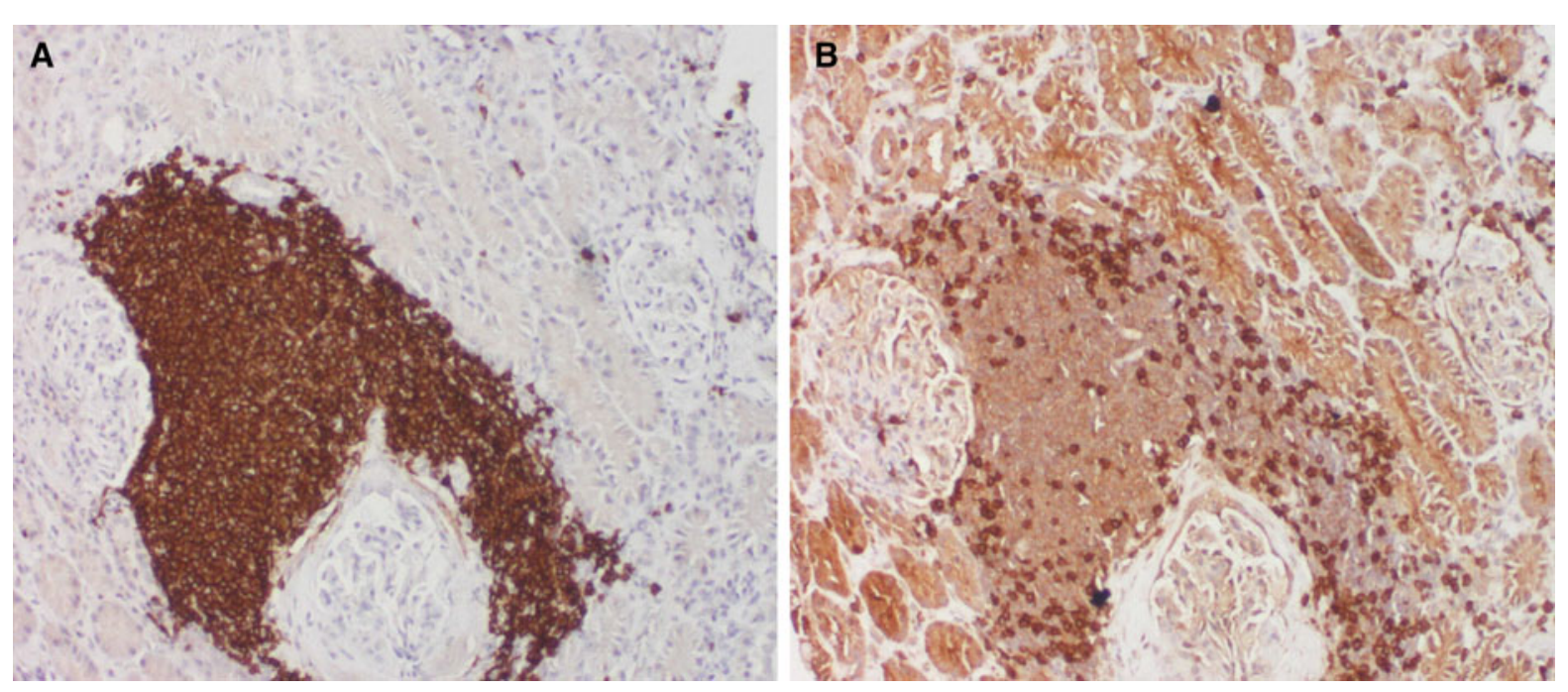

Fig. 2 Expression of CD20 $(\mathbf{a} \times 100)$ and CD3 $(\mathbf{b} \times 100)$
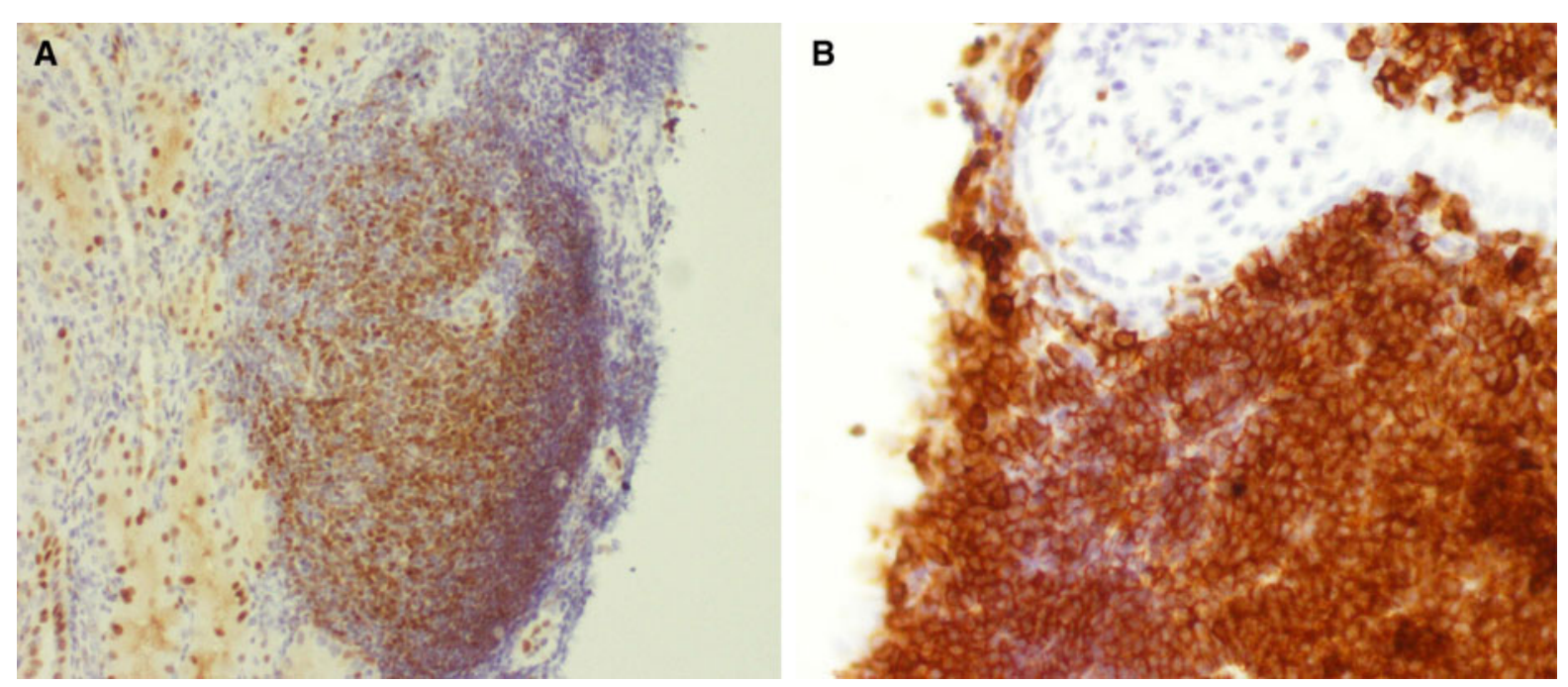

signs of glomerular sclerosis were present in several glomeruli. A striking feature of Bowman's capsule thickening mainly in glomeruli encircled by lymphoma infiltrations was clearly visible. Immunofluorescnece staining showed $\mathrm{C}_{3}$ deposits in the subendothelial capillary space. In addition, only sparse mononuclear inflammatory infiltration was present within renal parenchyma as well as slight tubular injury in the form of epithelial cell edema and degeneration. The cervical lymph node biopsy

Fig. 3 Expression of cyclin D1 $(\mathbf{a} \times 100)$ and CD5 $(\mathbf{b} \times 200)$

Fig. 3 Expression of cyclin D1 $(\mathbf{a} \times 100)$ and CD5 $(\mathbf{b} \times 200)$ 


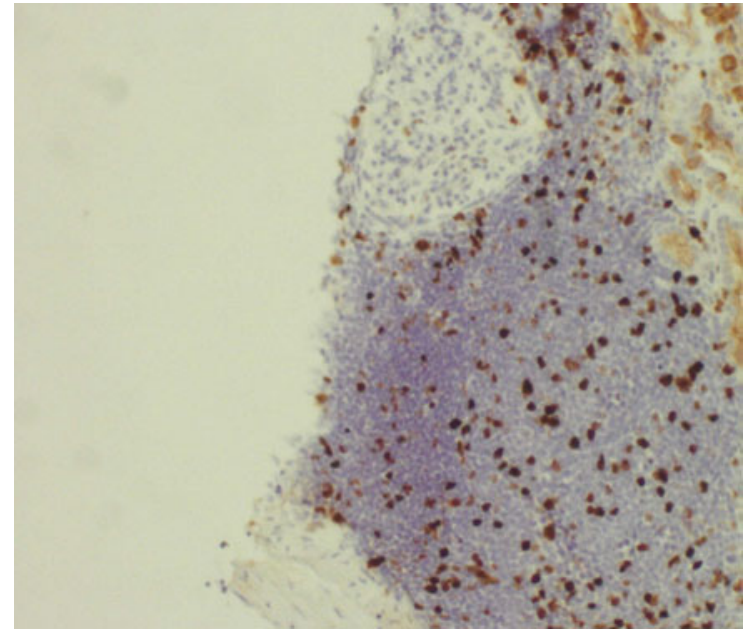

Fig. 4 Expression of Ki-67 in about $20 \%$ of nuclei $(\times 100)$

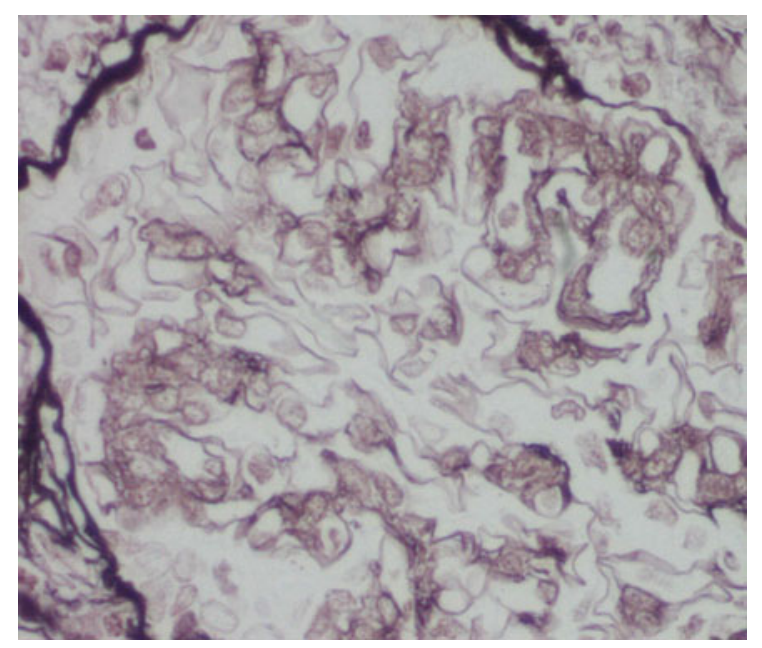

Fig. 5 Double contouring of basal membranes and segmental sclerosis of glomerulus $(\times 400)$

confirmed the diagnosis with the recognition of mantle cell lymphoma.

The tests performed 3 weeks after leaving the hospital showed further improvement in renal function, only small-degree proteinuria with disappearance of parenchymal edema in ultrasound imaging (left kidney length $119 \mathrm{~mm}$ and right kidney $115 \mathrm{~mm}$ ). Significant changes in clinical and biochemical outcomes 3 weeks after initial therapy are presented in Table 1. Patient was transferred to the Clinic of Hematology, in order to continue treatment.
Table 1 Significant changes in clinical and biochemical outcomes 3 weeks after initial therapy

\begin{tabular}{|c|c|c|}
\hline & Before therapy & After initial therapy \\
\hline Skin & $\begin{array}{l}\text { Hemorrhagic, } \\
\text { Henoch-Schönlein- } \\
\text { like purpura }\end{array}$ & $\begin{array}{l}\text { Slight (retracting) } \\
\text { rosacea-like } \\
\text { dermatitis }\end{array}$ \\
\hline \multicolumn{3}{|l|}{ Kidney } \\
\hline \multirow[t]{2}{*}{ Function } & $\begin{array}{l}\text { Acute kidney injury } \\
\text { (creatinine } \\
772.92 \mu \mathrm{mol} / 1, \\
\text { GFR-MDRD } 7 \mathrm{ml} / \\
\min / 1.73 \mathrm{~m}^{2} \text { ) }\end{array}$ & $\begin{array}{l}\text { Proper kidney } \\
\text { function (creatinine } \\
79.56 \mu \mathrm{mol} / \mathrm{l} \text {, GFR- } \\
\text { MDRD } 92 \mathrm{ml} / \mathrm{min} / \\
1.73 \mathrm{~m}^{2} \text { ) }\end{array}$ \\
\hline & $\begin{array}{l}\text { Nephrotic syndrome } \\
\text { (proteinuria of } \\
6.88 \mathrm{~g} / 24 \mathrm{~h} \text { ) }\end{array}$ & $\begin{array}{l}\text { Small-degree } \\
\text { proteinuria in spot } \\
\text { morning urine } \\
\text { sample }(0.25 \mathrm{~g} / 1)\end{array}$ \\
\hline \multirow[t]{2}{*}{$\begin{array}{l}\text { Ultrasound } \\
\text { imaging }\end{array}$} & $\begin{array}{l}\text { Enlargement (left } \\
\text { kidney-141 mm; } \\
\text { right kidney- } \\
134 \mathrm{~mm})\end{array}$ & $\begin{array}{l}\text { Correct length of } \\
\text { kidneys (left } \\
\text { kidney-119 mm; } \\
\text { right kidney- } \\
115 \mathrm{~mm} \text { ) }\end{array}$ \\
\hline & Parenchymal edema & $\begin{array}{l}\text { No abnormal } \\
\text { alterations }\end{array}$ \\
\hline \multicolumn{3}{|l|}{ Liver } \\
\hline Function & $\begin{array}{l}\text { Acute liver injury } \\
\text { (bilirubin } \\
\text { 131.67 } \mu \mathrm{mol} / 1, \\
\text { GGTP 2,938 U/l; } \\
\text { AST } 119 \mathrm{U} / 1, \text { ALT } \\
185 \mathrm{U} / \mathrm{l} \text { ) }\end{array}$ & $\begin{array}{l}\text { Normalization } \\
\text { (bilirubin } \\
22.23 \mu \mathrm{mol} / \mathrm{l} \text {; AST } \\
19 \mathrm{U} / \mathrm{l}, \text { ALT } 31 \mathrm{U} / \mathrm{l} \text { ) }\end{array}$ \\
\hline $\begin{array}{l}\text { Ultrasound } \\
\text { imaging }\end{array}$ & $\begin{array}{l}\text { Hepatomegaly } \\
\text { (length: } 160 \mathrm{~mm} \text { ) }\end{array}$ & $\begin{array}{l}\text { Hepatomegaly } \\
\text { (length: } 167 \mathrm{~mm} \text { ) }\end{array}$ \\
\hline \multicolumn{3}{|l|}{ Spleen } \\
\hline $\begin{array}{l}\text { Ultrasound } \\
\text { imaging }\end{array}$ & $\begin{array}{l}\text { Splenomegaly } \\
\quad \text { (length: } 137 \mathrm{~mm} \text { ) }\end{array}$ & $\begin{array}{l}\text { Almost normal spleen } \\
\text { length }(126 \mathrm{~mm})\end{array}$ \\
\hline
\end{tabular}

\section{Discussion}

Mantle cell lymphoma (MCL) is a rare aggressive lymphoid neoplasm occurring in about 3-7 \% of nonHodgkin (NHL) lymphomas in United States and Europe [1, 2]. Most frequent NHL infiltrating kidneys are recognized as extranodal cancers of marginal zone, especially MALT (mucose-associated lymphoid tissue lymphoma), DLBCL (diffuse large B-cell lymphoma) and Burkitt's lymphomas [10]. Seizure of the genitourinary tract by lymphoma occurs rarely, its incidence is estimated in about $5 \%$, in which renal involvement is most common and occurs in approximately $37 \%$ of cases. On the basis of retrospective studies, Da' as et al. [3] found that NHL were a rare cause of acute renal 
failure $(9.5 \%)$. Ultrasonographic findings are expressed as kidneys enlargement with a decreased echogenicity of the parenchyma.

Glomerulonephritis (GN), in the course of NHL is one of the causes of acute kidney injury (AKI). In most cases, membranoproliferative $\mathrm{GN}$, mesangial proliferative GN, crescenic GN or minimal change GN, as well as membranous GN and IgA nephropathy are recognized, and clinically expressed as nephrotic syndrome with microhematuria, seldom with reduced complement components or cryoglobulinemia [3]. Start of chemotherapy, resulting in partial remission of NHL, correlates with the decrease in the signs of GN and improved organ function [3, 4, 9]. Infiltration of renal parenchyma by lymphoma cells is very rare and is rated in about $1 \%$ of cases [3]. Most often, renal lymphoid infiltration is asymptomatic, but sometimes it can be a cause of acute tubulo-interstitial nephritis. Start of immunosuppressive treatment with a few 0.5-1.0 g intravenous doses of methylprednisolone administered every 1-2 days, then continued with oral prednisone, enables rapid improvement of renal function, although temporal renal replacement therapy is at times necessary [6, 7]. So far, eight cases of kidney impairment due to MCL have been described: four of them presenting proliferative $\mathrm{GN}$, one focal segmental glomerulosclerosis (FSGS), two renal MCL infiltration with AKI, and the last AKI due to acute tubulo-interstitial nephritis [3-9]. The presented case is the first announcement describing the coexistence of renal infiltration by MCL with secondary membranoproliferative subacute GN and AKI. There is no clear explanation of the cause of the patient's AKI. Renal failure occurred in the period of acute dermatitis and suggests diagnosis of post-infectious GN. Whereas participation of skin infection in the development of AKI may be important, the existence of chronic GN (at least from 2008) recognized in the interview seems to be more essential. The changes discovered in the renal biopsy showed a secondary GN with an indication of neoplastic process as the cause of the disease. On the other hand, untreated infiltration of the kidney with MCL could be the reason for their tubulo-interstitial inflammation and AKI [7]. Although renal biopsy showed only sparse mononuclear inflammatory infiltration within renal parenchyma and slight tubular injury, the examination took place 10 days after starting intravenous methylprednisolone and already achieved the returning of renal function (creatinine
$97.24 \mu \mathrm{mol} / \mathrm{l})$. Also, an improvement in renal function after infusions of methylprednisolone does not indicate clearly the cause of AKI with preserved diuresis. Such treatment is recommended as a part of the induction in rapidly progressing GN, acute glomerulopathies, as well as acute tubulo-interstitial renal inflammations. In the presented case, renal biopsy was performed after the improvement of renal function in order to determine diagnosis and further treatment. The diagnosis of MCL renal involvement and neoplastic generalization confirmed later in a lymph node biopsy has become the reason for systemic chemotherapy in the Clinic of Hematology.

\section{Summary}

The presented case demonstrates for the first time the possibility of renal infiltration by MCL concomitant with secondary membranoproliferative GN. It also shows the importance of the renal biopsy as a useful diagnostic tool in case of kidney impairment due to the lymphoma.

Open Access This article is distributed under the terms of the Creative Commons Attribution License which permits any use, distribution, and reproduction in any medium, provided the original author(s) and the source are credited.

\section{References}

1. Zhou Y, Wang H, Fang W et al (2008) Incidence trends of mantle cell lymphoma in the United States between 1992 and 2004. Cancer 113:791-798

2. Sant M, Allemani C, Tereanu C et al (2010) Incidence of hematologic malignancies in Europe by morphologic subtype: results of the HAEMACARE project. Blood 116: 3724-3734

3. Da'as N, Polliack A, Cohen Y et al (2001) Kidney involvement and renal manifestations in non-Hodgkin's lymphoma and lymphocytic leukemia: a retrospective study in 700 patients. Eur J Haematol 67:158-164

4. Rerolle JP, Thervet E, Beaufils H et al (1999) Crescentic glomerulonephritis and centrocytic lymphoma. Nephrol Dial Transplant 14:1744-1745

5. Karim M, Hill P, Pillai G et al (2004) Proliferative glomerulonephritis associated with mantle cell lymphomanatural history and effect of treatment in 2 cases. Clin Nephrol 61:422-428

6. Davies J, Healey DA, Wood KM et al (2007) Acute renal failure due to mantle cell lymphoma-a case report and discussion of the literature. Clin Nephrol 67:394-396 
7. Colak N, Dede F, Canbakan B et al (2007) Acute tubulointerstitial nephritis associated with mantle cell lymphoma presented as acute renal failure. Nephrology 12:107-108

8. Wong CF, Mohteshamzadeh M, Arsalanizadeh B et al (2007) Successful treatment of focal segmental glomerulosclerosis in association with mantle cell lymphoma. Ren Fail 29:363-366
9. Sellin L, Friedl C, Klein G et al (2004) Acute renal failure due to a malignant lymphoma infiltration uncovered by renal biopsy. Nephrol Dial Transplant 19:2657-2660

10. Schniederjan SD, Osunkoya AO (2009) Lymphoid neoplasms of the urinary tract and male genital organs: a clinicopathological study of 40 cases. Mod Pathol 22:10571065 